\title{
O SOFRIMENTO NO LAÇO ENTRE PAIS E FILHOS: OS CONTEXTOS, A PROBLEMÁTICA, $O$ TRABALHO TERAPÊUTICO E EDUCATIVO
}

DOI: http://dxdoi.org/10.11606/issn. 1981-1624.v20i1p12-14.

No contexto da pós-modernidade, enfrentamos nas instituições educativas ou de saúde mental uma precariedade dos laços, recebendo crianças ou adolescentes cada vez mais perdidos em um mundo sem barreiras e limites claros, com pais e famílias absorvidas em economias psíquicas de sobrevivência. As violências que testemunham mascaram, muitas vezes, situações de grande insegurança nos laços pais/filhos. Esse sofrimento pode ser causado por condições de precariedade social e/ou psíquica e por violências traumáticas transmitidas pelas gerações precedentes. Essas fragilizam a constituição dos laços primários, que são os primeiros funcionamentos de apropriação subjetiva (primeiras diferenciações, primeiros processos de simbolização), provocando, em cadeia, formas de impasse na integração da criança e do adolescente, e até mesmo do jovem adulto no universo escolar, social e cultural. Essas novas formas de trauma primário nos obrigam a uma reflexão tanto sobre o que continua quanto sobre as mutações no universo familiar e universo de nossas instituições, bem como sobre os dispositivos que devem ser inventados para acolher, conter e transformar essas ações em uma perspectiva de simbolização. 
Assim, iniciamos este Dossiê com um texto de Pierre Delion, professor e chefe do serviço de psiquiatria da criança e do adolescente no Centre Hospitalier Universitaire da cidade francesa de Lille, que trata da importância de um trabalho clínico com o rosto humano no tratamento de crianças psicóticas ou autistas, apoiando-se na noção de "constelação transferencial". Com base na riqueza da experiência do movimento de Psicoterapia Institucional e face à explosão da transferência nessas crianças, Delion mostra a importância de reunir todos os atores da instituição para partilhar as observações e trabalhar de modo associativo na elaboração dos indicadores da relação complexa da criança autista com o mundo. Entretanto, devido à crescente objetivação da abordagem do autismo realizada por meio de certo número de procedimentos hoje em voga, a abordagem do autismo inspirada na psicanálise viu-se contestada por certos lobbies, mais interessados em desenvolver uma abordagem reabilitadora. Lembrando a importância de um trabalho clínico com a criança e seus pais em torno de três dimensões complementares (educativa na família, pedagógica na escola, e chet gando ao caso, terapêutica no hospital-dia, se necessário), nosso autor insiste na necessidade de relações complementares entre os diferentes atores com o objetivo de desenvolverem coletivamente a função psicoterapêutica de continência.

Maurice Corcos, professor e chefe do serviço de Psiquiatria do Adolescente do Institut Mutualiste Montsouris de Paris, convida-nos a observar outra direção do sofrimento do laço pais/filhos: por meio das relações complexas da adolescente anoréxica com seus pais. A partir de uma abordagem transnosográfica e intergeracional, propõe-nos refletir sobre uma hipótese central para a psicopatologia dos transtornos do comportamento alimentar, seja o acontecimento advindo de uma falha da função materna quanto do investimento precoce da filha, que se traduz em um domínio sadomasoquista impedindo uma integração correta do feminino no momento da adolescência. Corcos insiste na frequência, na clínica dessas jovens anoréxicas, de experiências corporais que aludem a uma terceira mulher ou a uma imago "de avó", verdadeiros elementos traumáticos com alto poder melancólico que empurram a jovem em direção a uma espécie de rejeição de seu corpo.

Yolande Govindama, psicanalista e professora de psicologia clínica na Université de Rouen, na Normandia francesa, nos apresenta uma reflexão sobre os processos psíquicos operantes na parentalidade (termo criado nos últimos anos que resume o exercício das funções paterna e materna). Trata-se da reativação de fantasmas arcaicos (uma violência primitiva) ligados como colapsos a cenas infantis no caso de ter havido maus-tratos. Há uma predominância de modos de identificação projetiva patológica ou de sedução narcísica comprometidas em interações muito paradoxais. Essas relações, sob o modo de domínio, requerem o estabelecimento de um dispositivo específico. Como ilustrado por um caso clínico, essa "aliança terapêutica interdisciplinar" adquire a forma de 
uma correferência. Ela aí associa um trabalhador social que acompanha o pai em sua prática do laço, bem como um psicólogo clínico que sustenta o trabalho de observação mãe-bebê, permitindo a jovem mãe, apoiando-se também sobre os outros intervenientes, reinscrever-se em um processo de historização de sua própria vida e da vida de seu filho.

Em nosso próprio artigo, escrito com Teresa Rebelo, interessamo-nos pelo tornar-se adulto em suas ressonâncias com os sofrimentos primitivos. Observamos esses jovens adultos que se encontram, no fim da adolescência, aspirados por lógicas de autossabotagem no modo de adições, de isolamento do mundo, e até mesmo como fenômenos sectários. Enfatizamos o quanto essa negatividade deve ser colocada em perspectiva levando-se em conta a presença de elementos traumáticos. Estes derivam de traumas primários, mas também de violências transubjetivas, situações sociais ou comunitárias traumáticas que parasitam o processo de transmissão, impedindo o jogo criador na relação com as origens. Quando é difícil propor uma psicoterapia familiar, discutimos sobre a oportunidade de consultas terapêuticas abertas (consulta de um dos pais com o jovem adulto em um caso, consulta parental em outra situação clínica). O trabalho terapêutico se apoia em um dispositivo/enquadre aberto a uma coconstrução e sobre a utilização de mediações tais quais o genograma e as linhas de vida, sobre a análise da rede de contratransferências que se desenvolve entre os diferentes interventores. Assim, trabalhamos sobre as ressonâncias grupais fantasmáticas com vistas a produzir uma espécie de descondensação dos enredos traumáticos de forma a dar sustentação ao processo de simbolização.

Finalmente, apresentamos o texto de Karin Ensink, professora associada da Université de Laval de Quebec, e de Peter Fonagy, psicanalista do Anna Freud Center, pesquisador na University College de Londres, dentre outros, que discute o papel protetor da mentalização como fator de resiliência em caso de pais confrontados na infância a traumas relacionais ou a um clima de violência. As crianças que crescem com figuras de apego inseguras, que impõem maus tratos, correm o risco de desenvolver laços incoerentes com seus pais, tornando complexo o estabelecimento de condutas de mentalização ou funcionamento reflexivo. Quando essas crianças se tornam mães, um trabalho terapêutico focalizado na mentalização das experiências traumáticas pode aumentar a capacidade reflexiva em momentos de fragilidade como, por exemplo, na gravidez e maternidade.

Didier Drien

Tradução: Teresa Rebelo 